\title{
Synthesis and Cytotoxic Activity of the Products of Addition of Thiophenol to Sesquiterpene Lactones
}

\author{
A. V. Semakov ${ }^{a}, 1$, L. V. Anikina ${ }^{a}$, and S. G. Klochkov ${ }^{a}$ \\ ${ }^{a}$ Institute of Physiologically Active Compounds, Russian Academy of Sciences, Chernogolovka, Moscow oblast, 142432 Russia \\ Received August 4, 2020; revised September 18, 2020; accepted September 21, 2020
}

\begin{abstract}
Derivatives of sesquiterpene lactones modified at the lactone ring with a thiophenol residue have been synthesized. The resulting conjugates with thiophenol have capacity for the oxidation-elimination reaction by the action of ROS of a tumor cell with the release of initial cytotoxic lactones. It has been proposed to use the resulting sulfur-containing conjugates as ROS-activated prodrugs of sesquiterpene lactones. The antiproliferative properties of the conjugates have been examined on tumor and pseudonormal cell lines. The cytotoxicity of the conjugates is lower than that of parent lactones; however, in some cases, as with the conjugates of alantolactone with artemisiten, it remains moderate in all tumor cell lines tested.
\end{abstract}

Keywords: thiophenol, prodrugs, reactive oxygen species, sesquiterpene lactones, cytotoxicity in vitro, MTT-test DOI: $10.1134 / \mathrm{S} 106816202104018 \mathrm{X}$

\section{INTRODUCTION}

Sesquiterpene lactones (SLs) are a wide class of compounds, predominantly of plant origin. Its members are often characterized by pronounced cytotoxic activity toward tumor cells [1, 2]. For the most part, only those lactones have cytotoxic activity that carry a conjugated double bond at the lactone ring and are capable of entering into the Michel addition reaction with nucleophiles. In a living cell, a plenty of molecules with amine and thiol nucleophilic groups are found that serve as targets for the attack of SLs with the formation of a new covalent bond. However, the activating influence of the carboxyl group of the lactone ring on the double bond is not as strong; as a result, SLs possess a moderate capacity for the addition in the Michael reaction. Therefore, SLs are able to chemically bind only at the sites of those proteins that have high affinity to a particular SL molecule. Often these sites are the active centers of enzymes with hydrophobic pockets containing the thiol groups of cysteines. Different SLs inhibit a different set of enzymes. The ability to inhibit enzymes makes SLs promising agents for antitumor therapy. Among the most significant targets of SLs are the transcription

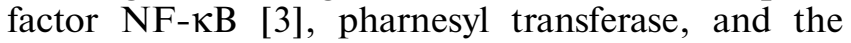
enzymes of the primary metabolism, including the glycolysis [4]. At the same time, SLs have some disadvantages that limit their application as antitumor

Abbreviations: ROS, reactive oxygen species; PE, petroleum ether; SL, sesquiterpene lactone; Chl, chloroform; EA, ethyl acetate; DCC, dicyclohexylcarbodiimide; $\mathrm{IC}_{50}$, the concentration that induces a $50 \%$ inhibition of the growth of cell population.

${ }^{1}$ Corresponding author: phone: +7 (919) 96-49-347; e-mail: L_vok@list.ru. agents: (1) SLs also act on other tissues, which leads to toxic effects at therapeutic doses; (2) in the course of time, liver enzymes restore the unsaturated bond at the lactone ring of SLs, which results in a loss of activity; and (3) SLs are often hydrophobic substances with low bioaccessibility. As a possible solution to overcome these problems, we have proposed to use SLs in the form of their conjugates with thiophenols.

From the chemistry of carbonyls, in particular lactones, it is known that carbonyls enter into the oxidation/elimination reaction with the substituents in the form of the thiophenol group in the $\alpha-[5,6]$ or $\beta$ position [7] to form enones by the action of various oxidizing agents, including hydrogen peroxide. SLs readily react with thiophenol in the Michael addition reaction. The resulting sulfides are also capable of entering into oxidative elimination reactions by the action of hydrogen peroxide; in this case, the reaction product is the initial lactone with an exo-methylene group in the lactone ring.

On the other hand, in the process of metabolism, reactive oxygen species (ROS) form in the cell, the main of which are superoxide anion and hydrogen peroxide. It has been found that the content of ROS in tumor cells is higher than in the cells of the corresponding normal tissue. This is associated with both a higher rate of ROS formation due to an unbalanced operation of the electron transport chain of mitochondria and a reduced capacity of tumor cells for the detoxication of ROS due to a lower activity of the enzymes responsible for the antioxidant protection of cells [8]. Because it is not important whether the oxidative elimination reaction of the conjugates of SLs with thiophenol occurs by the action of intracellular hydrogen peroxide or during the chemical synthesis, 
this feature of tumor cells can be used for the development of SL-based prodrug conjugates with a greater selectivity of cytotoxic action. Moreover, this approach allows the use of substituted thiophenols, which makes it possible to create SL-based prodrug conjugates with the required polarity. Earlier, the ROS-activated prodrugs of the lactone grossheimin (I) have been produced by the synthesis of its conjugates with thiophenols [9]. We propose to use this approach to obtain ROS-activated prodrugs based on other SLs. It is also known from the literature data about the synthesis, as intermediate substances, of the conjugates of alantolactone (II) [10] and isoalantolactone (III) [11] with thiophenol; however, nothing has been reported about their cytotoxic properties. Finally, it is also known from the literature data about the synthesis of a conjugate of the SL artemisitene (IV) with thiophenol [12] in the framework of searches for novel antimalarial drugs.

\section{RESULTS AND DISCUSSION}

As substrates for conjugates of SLs with thiophenol, SLs $(\mathbf{I}-\mathbf{X V})$ isolated from plant sources and SLs obtained from natural SLs by chemical modification were used. At present, a great number of SLs have been described [13, 14]; however, the overwhelming majority of these compounds are contained in plants in vanishingly low concentrations, or the plant raw material itself is unavailable. Therefore, we used those plant sources with a high SL content in dry raw material that either are commercially available (roots of elecampane Inula helenium L., an extract from the roots of costus saw-wort Sausserea lappa (Decne.) obtained by supercritical $\mathrm{CO}_{2}$ extraction) or were grown by ourselves (inflorescences of feverfew Tanacetum partenium L., leaves of bighead knapweed Centaurea macrocephala (Muss.-Puschk. ex Willd.)). Other lactones used were obtained from parent lactones in a semisynthetic way (Schemes 1-4).

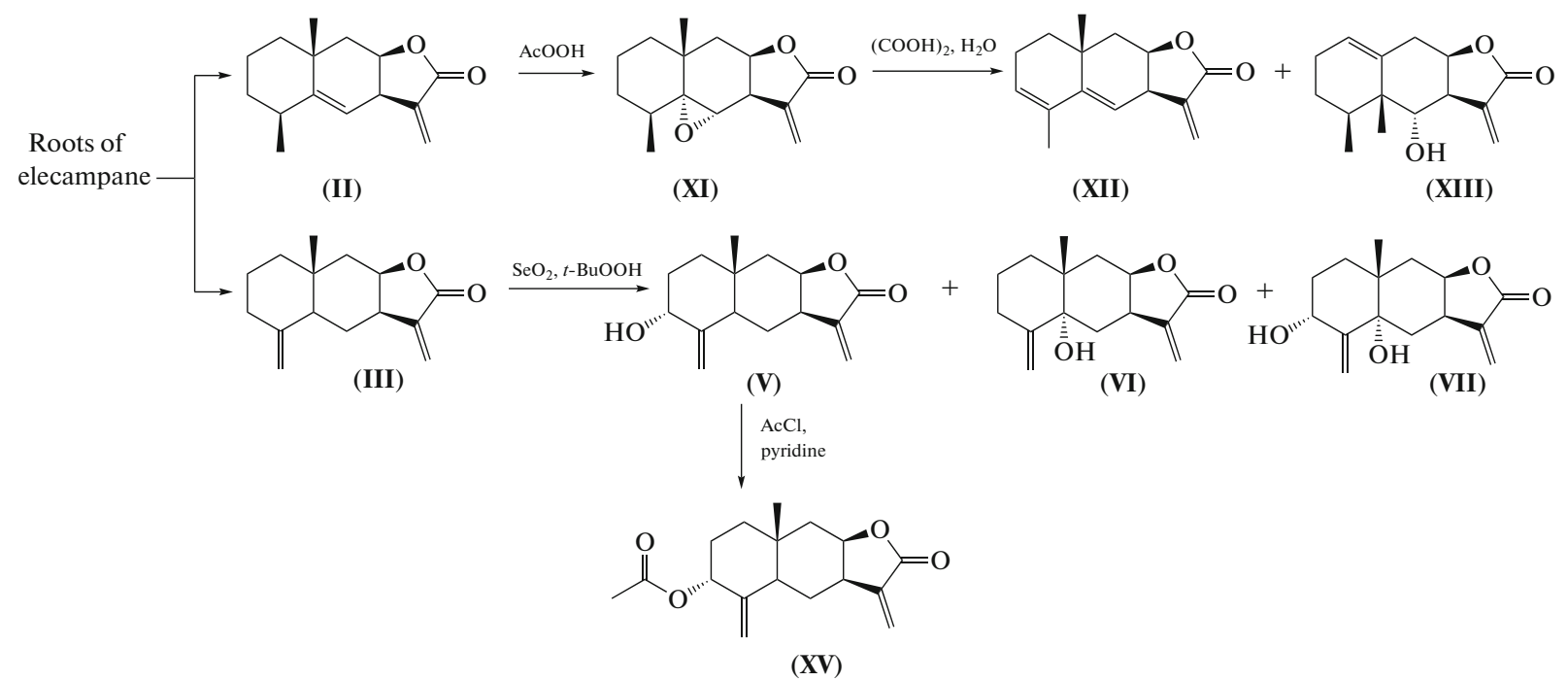

Scheme 1. Synthesis of sesquiterpene lactones from the lactones of elecampane (Inula helenium L.).

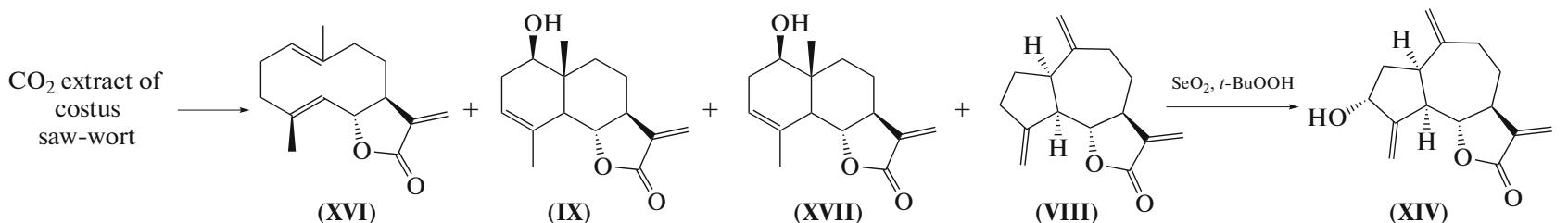

Scheme 2. Sesquiterpene lactones of costus saw-wort (costus, Sausserea lappa (Decne.)).

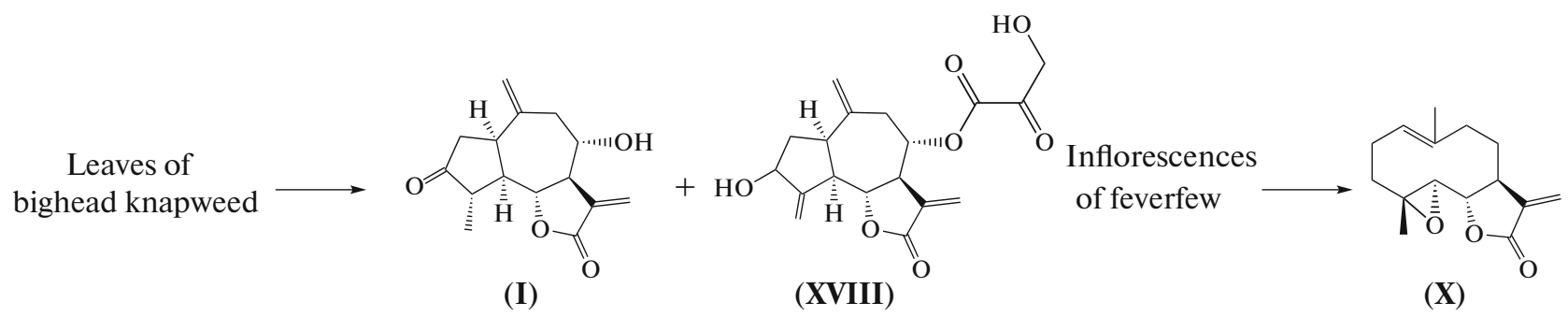

Scheme 3. Sesquiterpene lactones grossheimin (I), cynaropicrin (XVIII), and parthenolide (X) isolated from plants. 


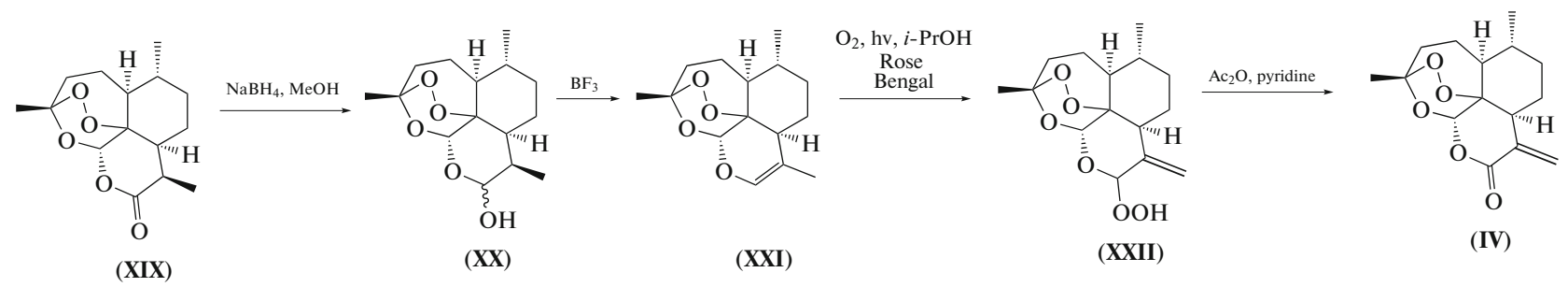

Scheme 4. Synthesis of artemisitene (IV).

The lactones from the roots of elecampane, alantolactone (II) and isoalantolactone (III), have similar properties, which makes their separation difficult. Besides, these two lactones can be isolated simultaneously by separating their mixture using chromatography on a column with silica gel impregnated with silver nitrate $[15,16]$; however, it is more feasible to obtain each lactone from the purified extract individually [17]. Thus, alantolactone (II) was obtained from a mixture of alanto- and isoalantolactone by the selective oxidation of isoalantolactone with selenium dioxide to another SL, isotelekin (V). The latter is readily separated by chromatography. Also, upon the oxidation of a mixture of compounds (II) and (III) with selenium dioxide, the SL telekin (VI) and lactone diol (VII) are obtained in minor amounts. Isoalantolactone (III) is partially separated from a mixture of lactones of elecampane by a fourfold recrystallization from hot $75 \%$ aqueous methanol. The methods for preparative separation of lactones from elecampane have been recently described in more detail in [17].

The main lactones from costus saw-wort roots are costunolide and dehydrocostus lactone (VIII). As a source for the isolation of the lactones costunolide (XVI) and lactone (VIII), we used an extract from the costus roots, obtained by supercritical $\mathrm{CO}_{2}$ extraction (Guangzhou Endless Biotech Co., China). The supercritical $\mathrm{CO}_{2}$ extract consisted of a mixture of SLs (25\%) and triglycerides (75\%). To remove triglycerides from the extract, SLs were withdrawn several times by hot aqueous acetonitrile and purified by filtration through silica gel. Dehydrocostus lactone (VIII) and costunolide (XVI) were separated on a column with impregnated silver nitrate. Minor lactones of costus saw-wort santamarine (IX) and reynosin (XVII) were isolated from the extract in smaller amounts; the lactones were also separated from each over on a column with impregnated silver nitrate (Scheme 2).

Other natural SLs used were isolated from dry plant raw material. For this purpose, based on the known techniques, we found an optimal way of obtaining the lactone fraction. It consisted in the following: dried ground parts of the plant were extracted with chloroform, evaporated, and dissolved in hot methanol, after which a saturated solution of lead acetate ( $20 \%$ by volume) was added in small portions under shaking and allowed to cool overnight. The liquid fraction was decanted from the precipitate of pigments, acids, and polyphenol compounds, washed with petroleum ether from highly lipophilic contaminations, and, after evaporating methanol from the water-methanol part at reduced pressure, diluted with water and extracted with ethyl acetate. Individual lactones were isolated from the enriched lactone fraction by preparative column chromatography. Using this method, the germacrene SL parthenolide $(\mathbf{X})$ with a yield of $0.78 \%$ was isolated from the inflorescences of feverfew, and the guainolides grossheimin (I) with a yield of $0.63 \%$ and cynaropicrin (XVIII) with a yield of $1.18 \%$ were isolated from the leaves of the largeheaded cornflower (Scheme 3).

Artemisinin (XIX) is a commercially available SL. However, it has no exomethylene group in the lactone ring and cannot enter into the Michael addition reaction. The SL artemisitene (IV) (also known as artemisininen) with an exomethylene group in the lactone ring was synthesized from dihydroartemisinin (XX), which is obtained from commercial sources, as well as obtained by the reduction of artemisinin (XIX) with sodium borohydride [18]. The method is based on the known technique for the synthesis of artemisiten (IV) [19]. It consists in the dehydrogenation of dihydroartemisinin (XX) with the formation of anhydrodihydroartemisinin (XXI), which, by the action of singlet oxygen, gives hydroperoxide (XXII). By the action of acetic anhydride in pyridine, the latter forms lactone (IV). In the original variant, intermediate (XXI) is synthesized from dihydroartemisinin (XX) using DCC as a dehydrating agent with a quantitative yield. However, the reproduction of the synthesis of compound (XXI) by the method of El-Feraly et al. [19] gave the wanted product only with a yield of $63.7 \%$ of the theoretical. Dicyclohexylurea and the by-product of the reaction make further work-up of the reaction mixture difficult. It was found to be more feasible at this stage to replace DCC as a dehydrating agent with boron trifluoride [20], which increases the yield to quantitative and simplifies the purification of the product. At the next stage, the reaction with singlet oxygen was carried out in the presence of the Rose Bengal photosensitizer in the reaction medium. The yield at this stage is low even with a long irradiation time, which makes it a bottleneck in the scheme of artemisitene (IV) synthesis (Scheme 4).

Some of lactones used were obtained in a semisynthetic way from natural lactones isolated from plant sources. Thus, epoxyalantolactone (XI) was obtained with a quantitative yield by the epoxidation of alantolactone (II) under the action of peracetic acid accord- 
ing to the known method [21]. Then, from epoxyalantolactone (XI), alantodiene (XII) and eremophilanic lactone (XIII) were synthesized under the action of oxalic acid in an aqueous medium [21]. Isozaluzanin C (XIV) was obtained as the main product of the allylic oxidation of dehydrocostus lactone (VIII) in the reaction with selenium dioxide. Isotelekin acylated at the alcohol group (XV) was obtained in the conventional way, by the reaction of lactone (V) with acyl chloride in pyridine (Scheme 1).

As known, SLs readily enter into the Michael addition reaction with thiols in the lactone ring [22, 23], including thiophenol [9]. The Michael reaction with thiophenol does not proceed in pure methanol in the absence of catalysis even during long-term incubation, but it occurs rapidly after the addition of the base triethylamine, which agrees with the literature data [9, 24]. Using this reaction, conjugates with thiophenol (Ia-XVa) were obtained from the earlier synthesized SLs (I-XV) (Scheme 5). The yields of the reaction products are given in Table 1 . We have recently described the preparation of the conjugates of lactones from elecampane (II) and (III) with thiophenol and selenophenol [25]. The standard method for the isolation of the reaction product (method A) involves the evaporation of the reaction mixture, washing of the residue in a funnel from thiophenol traces with a car- bonate solution, and crystallization in the cold from the minimal amount of methanol. The conjugates of lactones that precipitate from methanol are purified by simple distillation of the solvent and additional washing with methanol (method B). In the case that, along with the main product, contaminations were found in the reaction mixture, as indicated by TLC, the products were isolated by column chromatography (methods C and D). If the product was crystallized from the reaction mixture, but only partially, the stock solution was also evaporated, and the reaction mixture was work-up by the standard method (method E). With the long time of the reaction of alantolactone (II) with thiophenol, product (IIa) was isolated as an inseparable mixture of isomers at the $\mathrm{C}-11$ position. If the reaction is carried out for a few minutes followed immediately by the treatment of the reaction mixture, the reaction product is only one pure isomer. In the case of the other lactones, adducts were isolated as a single isomer, irrespective of the reaction time. On the whole, the addition of thiophenol to a SL is completed within a few minutes, and there is no need to conduct it for several days; however, a long reaction time sometimes allows the products to crystallize directly from the reaction mixture, which makes it possible to purify reaction products by simple filtration.

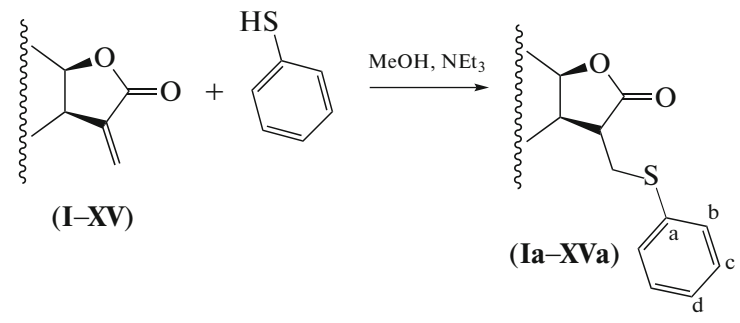

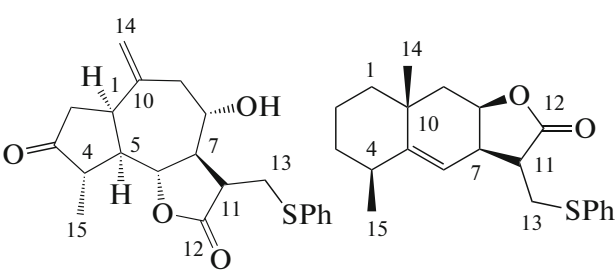

(Ia)

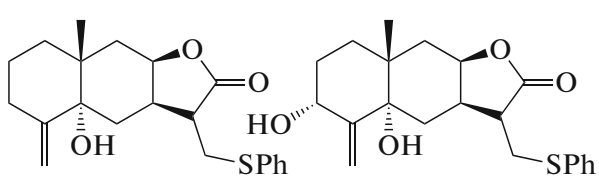

(VIa)<smiles>C[C@H]1CCC[C@@]2(C)C[C@H]3OC(=O)[C@@H](C[Sb]c4ccccc4)[C@H]3[C@H]3O[C@]132</smiles>

(XIa) (VIIa)<smiles>CC1=CCC[C@]2(C)CC3OC(=O)C(Cc4ccccc4)C3C=C12</smiles>

(XIIa)

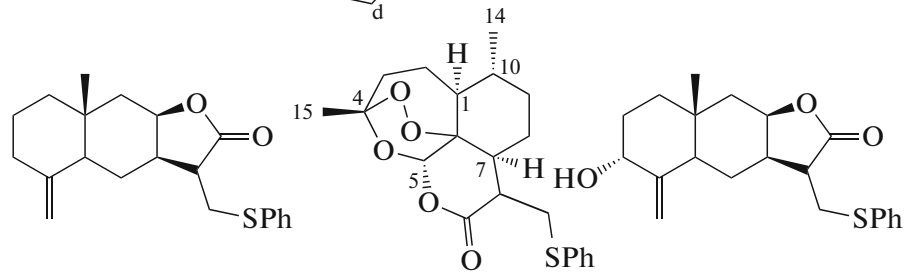
(IIIa)<smiles></smiles>

(VIIIa)
(IVa)<smiles>CC1=CC[C@@H](O)[C@]2(C)CC[C@H]3C(CS)C(=O)O[C@H]3[C@H]12</smiles>

(IXa)
(Va)

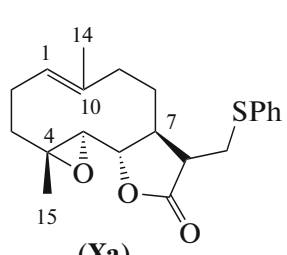

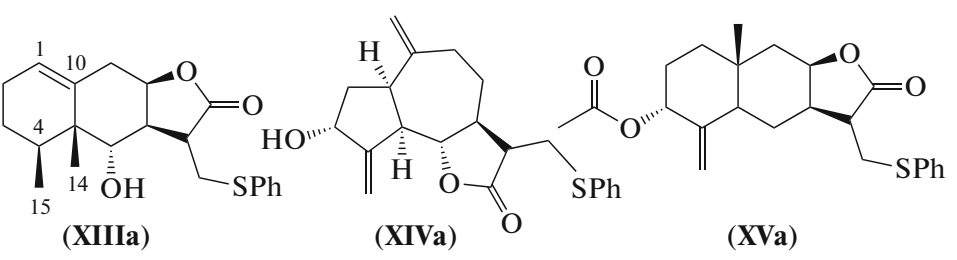

Scheme 5. Conjugates of sesquiterpene lactones with thiophenol (Ia-XVa). 
Table 1. Yields of the products of the addition of thiophenol and lactones

\begin{tabular}{c|c|c|l}
\hline Initial lactone & Method & Yield, \% & Reaction time \\
\hline (I) & E & 100 & 3 days \\
(II) & A & $89.0 *$ & 3 days \\
(III) & B & 100 & 10 min \\
(IV) & A & 100 & 3 days \\
(V) & D & 60.3 & 3 days \\
& B & 38.5 & 3 days \\
(VI) & E & 61.5 & 3 days \\
(VII) & C & 56.6 & 3 days \\
(VIII) & A & 100 & 3 days \\
& B & 92.0 & 14 days \\
(IX) & C & 38.5 & 3 days \\
(X) & D & 76.4 & 1 day \\
(XI) & B & 93.4 & 3 days \\
(XII) & A & 98.6 & 3 days \\
(XIII) & A & 92.2 & 7 days \\
(XIV) & C & 91.4 & 18 h \\
(XV) & A & 81.6 & 3 days \\
\hline
\end{tabular}

* Reaction product in the form of a mixture of isomers.

SLs exhibit the cytotoxic effect due to the presence of an electron-deficient double bond in the lactone ring. The conjugates of SLs with thiophenol are devoid of this group; however, they act as prodrugs of their corresponding initial lactones. By the action of intracellular ROS, the sulfide group of thiophenol adducts (Ia-XVa) is oxidized to sulfoxide or sulfone, which leads to subsequent gradual elimination with the formation of the initial active SL and sulfinic or sulfonic acid. Thus, the concentration of ROS inside the cell, which can vary in various tumor lines, is of crucial importance for the manifestation of the cytotoxic effect of thiophenol adducts of SLs.

The cytotoxic activity of the resulting conjugates of SLs with thiophenol was tested on four tumor cell lines (RD, HCT116, HeLa, A549) and one pseudonormal cell line (HEK293) (Table 2). It is quite expected that the cytotoxicity of sulfur-containing prodrug conjugates $(\mathbf{I a}-\mathbf{X V a})$ is lower than that of pure SLs $(\mathbf{I}-\mathbf{X V})$ almost in all cases. However, the fall in cytotoxicity $\left(\mathrm{IC}_{50}\right)$ is different in case of both different lactones and different cell lines. The cytotoxic activity of some conjugates, such as the conjugates of santamarine (IXa), telekin (VIa), isozaluzanin C (XIVa), and grossheimin (Ia), is low $\left(\mathrm{IC}_{50}>100 \mu \mathrm{M}\right)$ in all tumor lines tested. This is partially due to the lower cytotoxicity of lactones by themselves. On the other hand, it is known from the literature sources [9] that one of the conjugates we obtained, an adduct of grosshemin with thiophenol (Ia), possesses a moderate cytotoxicity $\left(\mathrm{IC}_{50}=\right.$
11.2 $\mu \mathrm{M}$ ) toward $\mathrm{KB}$ cells, which may be due to enhanced sensitivity of this cell line to lactone (I). The other prodrug conjugates we obtained retain moderate cytotoxicity $\left(\mathrm{IC}_{50}=5.8-38.4 \mu \mathrm{M}\right)$ in all lines tested. Among these, the conjugates of alantolactone (IIa) and artemisitene (IVa) merit attention as the most active. In the first case, the satisfactory cytotoxic activity of the prodrug conjugate (IIa) is due to a high activity of the initial lactone (II). In the second case, the activity of conjugate (IVa) differs little from that of the initial lactone (IV), which indicates a rapid decomposition of conjugate (IVa) after the entry into the cell. The two compounds, the conjugates of alantolactone (IIa) and artemisiten (IVa) are suitable for further structure optimization by introducing the substituents into the thiophenol moiety.

A shortcoming of the conjugates of this kind is a high hydrophobicity, which is even higher than that of initial SLs. However, in the future it can be eliminated by using substituted thiophenols in the synthesis of prodrugs. In this work, the viability of the approach itself to the synthesis of ROS-activated sulfur-containing prodrugs from SLs with different carbon backbones and cytotoxic activity was tested and confirmed.

\section{EXPERIMENTAL}

Materials and methods. NMR spectra $(\delta$, ppm; $J, \mathrm{~Hz}$ ) were recorded in $\mathrm{CDCl}_{3}$ (unless otherwise indicated) on a Spectrospin device $\left(200 \mathrm{MHz}\right.$ for ${ }^{1} \mathrm{H}$ and $50 \mathrm{MHz}$ for ${ }^{13} \mathrm{C}$ ) (Bruker, United States) using a residual signal of the solvent $\mathrm{CHCl}_{3}(\delta 7.27)$ as an internal standard; the symbols $a$ and $b$ in the deciphering of the spectrum denote nonequivalent protons at one carbon atom. The assignment of NMR signals was carried out by comparison with the data of $1 \mathrm{D}$ and $2 \mathrm{D}$ NMR spectra of lactones obtained by us earlier and the NMR spectra of lactones described in literature sources. The numbering of atoms in the spectra is as in Scheme 5. Elecampane roots were the products of PKF Fitofarm (Anapa, Russia).

TLC was performed on Silicagel $60 \mathrm{~F}_{254}$ plates (Merck, Germany). To detect substances, a solution of $4 \%$ phosphoromolybdic acid in ethanol was poured onto plates after which the plates were immediately heated with a heat gun to a temperature of $250^{\circ} \mathrm{C}$ until dark spots appeared. Also, to detect spots by TLC, plates were sprayed with an anisaldehyde solution $(75 \mathrm{~mL}$ of ethanol, $1 \mathrm{~mL}$ of acetic acid, $2.5 \mathrm{~mL}$ of sulfuric acid, $2 \mathrm{~mL}$ of anisaldehyde) and heated with a heat gun $\left(250^{\circ} \mathrm{C}\right)$ until the development of multicolored spots.

Isolation of the lactones grosheimin (I) and cynaropicrin (XVIII) from the leaves of bighead knapweed. Bighead knapweed (grosshemia large-headed, Centaurea macrocephala (Muss.-Puschk. ex Willd.)) was seeded and grown on the territory of the village of Ostankino, Borskii district, Nizhny Novgorod region. Leaves were collected and dried throughout summer 
Table 2. Cytotoxic activity of lactones and their conjugates

\begin{tabular}{|c|c|c|c|c|c|}
\hline \multirow{2}{*}{ Compound } & \multicolumn{5}{|c|}{$\mathrm{IC}_{50}, \mu \mathrm{M}$} \\
\hline & $\mathrm{RD}$ & HCT116 & HeLa & A549 & HEK293 \\
\hline (I) & $38.35 \pm 3.31$ & $17.80 \pm 2.16$ & $31.07 \pm 1.79$ & $44.06 \pm 0.68$ & $46.86 \pm 5.10$ \\
\hline (Ia) & $256.66 \pm 9.71$ & $160.43 \pm 25.94$ & $458.79 \pm 42.86$ & $557.26 \pm 38.62$ & -* $^{*}$ \\
\hline (II) & $6.23 \pm 0.11$ & $5.73 \pm 0.08$ & $5.38 \pm 0.04$ & $2.71 \pm 0.07$ & $15.44 \pm 1.27$ \\
\hline (IIa) & $18.42 \pm 0.94$ & $31.68 \pm 2.45$ & $34.33 \pm 0.02$ & $38.37 \pm 1.49$ & $34.24 \pm 0.18$ \\
\hline (III) & $10.30 \pm 0.01$ & $8.09 \pm 0.97$ & $5.94 \pm 0.06$ & $18.55 \pm 0.21$ & $35.68 \pm 1.52$ \\
\hline (IIIa) & $99.62 \pm 7.42$ & $124.77 \pm 3.48$ & $156.65 \pm 2.22$ & $74.66 \pm 6.95$ & $78.80 \pm 7.69$ \\
\hline (IV) & $8.23 \pm 0.01$ & $33.97 \pm 4.51$ & $2.95 \pm 0.04$ & $38.37 \pm 0.66$ & $7.98 \pm 0.11$ \\
\hline (IVa) & $14.93 \pm 0.38$ & $33.94 \pm 0.34$ & $5.82 \pm 0.01$ & $34.14 \pm 0.44$ & $11.80 \pm 1.49$ \\
\hline$(\mathbf{V})$ & $34.50 \pm 4.97$ & $47.55 \pm 3.38$ & $33.05 \pm 0.44$ & $43.27 \pm 1.29$ & $36.35 \pm 0.33$ \\
\hline (Va) & $76.94 \pm 8.99$ & $79.84 \pm 3.28$ & $100.80 \pm 1.16$ & $102.38 \pm 5.71$ & $67.10 \pm 5.85$ \\
\hline (VI) & $63.58 \pm 1.12$ & $22.15 \pm 0.02$ & $28.97 \pm 2.91$ & $46.30 \pm 5.39$ & $22.17 \pm 0.63$ \\
\hline (VIa) & $130.54 \pm 1.88$ & $139.10 \pm 5.10$ & $202.17 \pm 3.83$ & $638.91 \pm 10.54$ & $153.85 \pm 9.29$ \\
\hline (VII) & $20.30 \pm 0.56$ & $34.76 \pm 5.66$ & $24.47 \pm 0.96$ & $79.87 \pm 10.10$ & $17.52 \pm 2.91$ \\
\hline (VIIa) & $104.36 \pm 2.95$ & $127.87 \pm 3.49$ & $78.20 \pm 6.91$ & $185.29 \pm 8.98$ & $69.23 \pm 4.70$ \\
\hline (VIII) & $61.89 \pm 2.96$ & $37.48 \pm 2.51$ & $10.11 \pm 0.13$ & $34.22 \pm 1.62$ & $20.92 \pm 0.69$ \\
\hline (VIIIa) & $36.86 \pm 0.57$ & $54.48 \pm 9.09$ & $60.51 \pm 4.48$ & $66.69 \pm 3.82$ & $57.72 \pm 0.06$ \\
\hline (IX) & $88.27 \pm 5.68$ & $99.67 \pm 8.35$ & $77.71 \pm 4.73$ & $155.05 \pm 6.14$ & $66.08 \pm 2.89$ \\
\hline (IXa) & $231.90 \pm 7.99$ & $-^{*}$ & $-^{*}$ & $686.75 \pm 40.24$ & $124.57 \pm 3.35$ \\
\hline$(\mathrm{X})$ & $15.69 \pm 3.45$ & $34.01 \pm 2.32$ & $15.58 \pm 0.43$ & $64.31 \pm 2.85$ & $67.29 \pm 4.58$ \\
\hline (Xa) & $61.89 \pm 2.96$ & $74.45 \pm 3.17$ & $81.45 \pm 5.96$ & $185.00 \pm 11.02$ & $100.41 \pm 1.38$ \\
\hline$(\mathbf{X I})$ & $13.27 \pm 0.20$ & $30.56 \pm 0.94$ & $6.23 \pm 0.73$ & $31.54 \pm 2.44$ & $8.60 \pm 0.22$ \\
\hline (XIa) & $46.31 \pm 3.76$ & $155.20 \pm 2.14$ & $196.41 \pm 8.73$ & $146.48 \pm 15.65$ & $57.45 \pm 3.03$ \\
\hline (XII) & $3.60 \pm 0.25$ & $6.99 \pm 0.46$ & $41.03 \pm 3.13$ & $74.68 \pm 7.54$ & $29.64 \pm 3.88$ \\
\hline (XIIa) & $18.22 \pm 1.44$ & $44.93 \pm 3.24$ & $18.33 \pm 0.76$ & $48.84 \pm 0.92$ & $32.66 \pm 3.11$ \\
\hline (XIII) & $17.47 \pm 0.15$ & $21.54 \pm 3.59$ & $20.39 \pm 0.79$ & $91.56 \pm 3.13$ & $34.05 \pm 2.23$ \\
\hline (XIIIa) & $24.15 \pm 0.27$ & $36.48 \pm 1.57$ & $31.46 \pm 1.82$ & $88.78 \pm 1.54$ & $28.46 \pm 1.49$ \\
\hline$(\mathbf{X I V})$ & $100.04 \pm 2.72$ & $137.75 \pm 10.20$ & $190.56 \pm 2.38$ & $347.17 \pm 11.65$ & $-*$ \\
\hline (XIVa) & $123.84 \pm 3.87$ & $143.47 \pm 16.75$ & $173.44 \pm 21.76$ & $238.36 \pm 19.88$ & $112.72 \pm 5.80$ \\
\hline$(\mathbf{X V})$ & $70.27 \pm 2.01$ & $33.06 \pm 3.00$ & $21.04 \pm 0.48$ & $74.29 \pm 0.13$ & $29.86 \pm 0.63$ \\
\hline (XVa) & $237.99 \pm 7.20$ & $191.08 \pm 22.78$ & $334.83 \pm 19.13$ & $581.64 \pm 7.71$ & $165.32 \pm 19.38$ \\
\hline
\end{tabular}

* A dash denotes the absence of cytotoxicity in the MTT test $\left(\mathrm{IC}_{50}>600 \mu \mathrm{M}\right)$.

2017, beginning from the onset of the flowering period. Dried leaves (442.5 g) were ground manually and extracted with $2 \times 5 \mathrm{~L}$ of chloroform for several days. After evaporating chloroform extracts under reduced pressure, an extract weighing $24.0 \mathrm{~g}$ was obtained. The extract was dissolved in methanol $(200 \mathrm{~mL})$, a saturated lead acetate solution $(50 \mathrm{~mL})$ was gradually added in a water bath $\left(70^{\circ} \mathrm{C}\right)$ while shaking the flask, and the mixture was allowed to cool slowly to room temperature. After a night, the mixture was decanted from the sediment and washed in a funnel with petroleum ether $(3 \times 50 \mathrm{~mL})$; the watermethanol portion was evaporated under reduced pressure until easily volatile methanol was removed, the residue was diluted with water $(150 \mathrm{~mL})$ and ethyl acetate $(2 \times 150 \mathrm{~mL})$, after which organic layers were evaporated and dried under vacuum to give $9.31 \mathrm{~g}$ of the substance in the form of foam. The extract was chromatographed on a column with silica gel in a Chl/EA system $9: 1$ and then in Chl/acetone $9: 1$, $\mathrm{Chl} /$ acetone $4: 1$, Chl/acetone $7: 3$, and $\mathrm{Chl} / \mathrm{MeOH}$ $9: 1$. Mixed fractions were chromatographed again. The composition of fractions was controlled in a $\mathrm{Chl} /$ acetone system $2: 1$. In total, $2.768 \mathrm{~g}$ of grossheimin (I) in the form of large, nearly cubic crystals and $5.243 \mathrm{~g}$ of cynaropicrin (XVIII) in the form of amorphous solid foam were obtained. The NMR spectra of the lactones grossheimin (I) $[9,26]$ and 
cynaropicrin (XVIII) [26] are similar to those described earlier.

Preparation of alantolactone (II) and the products of allylic oxidation of isoalantolactone. A preliminarily purified [17] mixture of lactones from elecampane high (Inula helenium L.) (78.9 g) was dissolved under stirring in a flask in $\mathrm{CH}_{2} \mathrm{Cl}_{2}(350 \mathrm{~mL})$, after which selenium dioxide $(2 \mathrm{~g})$ and $70 \% \mathrm{t}$-BuOOH $(40 \mathrm{~mL})$ were added. The mixture was stirred for $5 \mathrm{~h}$ at room temperature and left overnight at $4^{\circ} \mathrm{C}$. The solvent was distilled under low pressure and thoroughly dried under vacuum. The product was purified by column chromatography on silica gel and eluted with benzene and then with benzene/EA $19: 1$, benzene/EA $9: 1$, benzene/EA $8: 2$, benzene/acetone $8: 2$, and benzene/isopropanol $1: 1$. From the column, fractions were successively eluted containing pure alantolactone (II), $33.9 \mathrm{~g}$, yellow oil rapidly congealing into a white solid substance $\left(R_{\mathrm{f}} 0.71\right.$ in TLC in benzene/EA $\left.9: 1\right)$; then telekin (VI) $7.4 \mathrm{~g}\left(R_{\mathrm{f}} 0.32\right.$ in TLC in benzene/EA $9: 1)$; isotelekin (V) $31.6 \mathrm{~g}\left(R_{\mathrm{f}} 0.16\right.$ in TLC in benzene/EA $9: 1)$; and lactone (VII) $3.29 \mathrm{~g}\left(R_{\mathrm{f}} 0.26\right.$ in TCX in benzene/acetone $9: 1)$. The NMR spectra of alantolactone (II) [21], telekin (VI) [27], isotelekin (V) [27], and lactone (VII) [27] are similar to those described earlier.

Synthesis of artemisitene (IV). Dehydration of dihydroartemisinin $(X X)$. Diethyl ether (1 L) was added to a 2-L flask, and commercially available dihydroartemisinin (XX) $(20 \mathrm{~g}, 70.3 \mathrm{mmol})$ was suspended in it. The flask was cooled to $0^{\circ} \mathrm{C}$ in an ice bath, and boron trifluoride etherate $(30 \mathrm{~mL})$ was added dropwise with rigorous stirring on a magnetic stirrer, after which the flask was closed with a stopper, and the mixture was left to stir for an additional $24 \mathrm{~h}$ on cooling. The fully transparent reaction mixture was washed in portions with a saturated $\mathrm{NaHCO}_{3}$ solution, organic layers were combined, ether was distilled, and the residue was rapidly chromatographed on a column with silica gel and eluted with a benzene/EA mixture $10: 1$. Anhydrodihydroartemisinin (XXI) was obtained with a quantitative yield in the form of a white solid substance.

The reaction of anhydrodihydroartemisinin (XXI) with singlet oxygen. Isopropanol $(250 \mathrm{~mL})$, anhydrodihydroartemisinin (XXI) (5 g, $18.8 \mathrm{mmol}$ ), and Rose Bengal $(100 \mathrm{mg})$ were added to a $500-\mathrm{mL}$ flask equipped with a magnetic stirrer. A bubbler with a glass filter from a Drexel bottle was inserted into the flask. A flow of dry air passed through the column with alkali was fed to the bubbler. The flow rate was controlled by a capillary installed at the pump inlet. At a distance of $10 \mathrm{~cm}$ from the flask, a DRL-125 high-pressure mercury lamp was installed, which was switched into the circuit through a PRA-125 choke. The mixture in the flask was left to vigorously stir under simultaneous passage of an air stream and illumination. At regular intervals, evaporated isopropanol was added to the reaction mass. After $24 \mathrm{~h}$ of the reaction, the solvent was distilled under reduced pressure, and the residue was dissolved in chloroform, applied to a column with silica gel, and eluted with a benzene/EA mixture 9: 1 . Hydroperoxide (XXII) (2.879 g, $9.7 \mathrm{mmol})$ was obtained with a yield of $51.6 \%$.

Conversion of hydroperoxide (XXII) into lactone (IV). Hydroperoxide (XXII) (2.879 g) obtained at the previous stage was dissolved in a mixture of acetic anhydride $(20 \mathrm{~mL})$ and pyridine $(1 \mathrm{~mL})$ and stirred for $2 \mathrm{~h}$ on a magnetic stirrer. The mixture was poured into a saturated aqueous $\mathrm{NaHCO}_{3}$ solution and left under stirring until the layer of acetic anhydride dissolved. Chloroform was added to the flask, and after the separation in a separating funnel, the organic layer was dried over $\mathrm{Na}_{2} \mathrm{SO}_{4}$ overnight. After the distillation of the solvent, $2.641 \mathrm{~g}(9.4 \mathrm{mmol}, 97 \%)$ of artemisitene (IV) was obtained as a white solid substance. The NMR spectrum of artemisitene (IV) is similar to that described earlier [28].

Isolation of lactones of costus. A supercritical $\mathrm{CO}_{2}$ extract of costus roots (costus saw-wort, Sausserea lappa (Decne.)) was derived from a commercial source (Guangzhou Endless Biotech Co., China). In a 2-L separatory funnel, the $\mathrm{CO}_{2}$ extract $(400 \mathrm{~mL})$ was diluted in portions with water and chloroform, and organic layers were separated, dried over $\mathrm{Na}_{2} \mathrm{SO}_{4}$, and filtered through paper filters, after which the solvent was distilled under reduced pressure. In the 2-L flask, acetonitrile $(600 \mathrm{~mL})$ was added to the $\mathrm{CO}_{2}$ extract purified from mechanical and polar contaminations, the mixture was brought in a water bath to boiling under stirring, and a still hot $\mathrm{MeCN}$ layer was decanted from the colorless oil composed entirely of triglycerides. Water $(60 \mathrm{~mL}, 10 \%$ of the volume of $\mathrm{MeCN}$ ) was added to the acetonitrile extract, the mixture was also heated in a water bath to boiling and decanted from the oil on the bottom, and the solvent was distilled. An extract (114 g) predominantly composed of SLs was obtained. The resulting $\mathrm{MeCN}$ extract was fractionated on a column with silica gel, and the composition of fractions was monitored by $\mathrm{TLC}$ in a $\mathrm{PE} / \mathrm{Et}_{2} \mathrm{O}$ system $15: 5$. Fractions containing a mixture of costunolide (XVI) and dehydrocostus lactone (VIII) were combined, evaporated, and separated in a funnel between $\mathrm{MeCN}$ and $\mathrm{PE}$; the $\mathrm{MeCN}$ layer was separated and evaporated. A part of kostunolide was removed by crystallization from $\mathrm{PE}$ at $-20^{\circ} \mathrm{C}$, and the supernatant was evaporated and chromatographed on a column with silica gel impregnated with $5 \%$ silver nitrate. Fractions containing pure dehydrocostus lactone (VIII) as oil solidifying into long colorless prisms were obtained with a yield of $48.4 \mathrm{~g}$; then, fractions were obtained that gave $7.71 \mathrm{~g}$ of costunolide (XVI), which rapidly isomerized into other lactones in the presence of $\mathrm{AgNO}_{3}$ traces. More polar fractions of the $\mathrm{MeCN}$ extract were combined and chromatographed on silica gel; elution was with a PE/EA mixture $2: 1$. 
Fractions (7.9 g) rich in santamarine (IX) and reynosin (XVII) were collected; after chromatography on silica gel with impregnated silver nitrate, they give a small amount of pure lactones (IX) and reynosin (XVII). Then, lactones purified on a column with silver were filtered through a layer of aluminum oxide to remove residual silver nitrate. The NMR spectra of dehydrocostus lactone (VIII) [29], costunolide (XVI) [29], santamarine (IX) [30, 31], and reynosin (XVII) $[30,31]$ are similar to those described earlier.

Isolation of parthenolide (X). The feverfew (Tanacetum partenium L.) of the nonvarietal form was seeded and grown on the territory of the Institute of Physiologically Active Compounds (Chernogolovka, Moscow oblast); from July to August 2018, inflorescences of the plant were collected with an interval of two weeks. Dried inflorescences of feverfew (356.5g) were ground on a laboratory mill and extracted twice with a mixture of benzene with ethyl acetate $(5 \mathrm{~L})$ at room temperature. The solvent was distilled, the extract $(36.03 \mathrm{~g})$ was diluted with methanol $(450 \mathrm{~mL})$, and a saturated aqueous lead acetate solution $(50 \mathrm{~mL})$ was added with heating in a water bath $\left(50^{\circ} \mathrm{C}\right)$, after which the water bath was allowed to cool gradually. After a night, the water-methanol fraction was decanted and washed in a funnel with hexane. The hexane fraction $(2.6 \mathrm{~g})$ contained camphor and fats. From the rest of the water-methanol fraction, methanol was distilled off under reduced pressure, chloroform and water were added to the residue, the chloroform fraction weighing $16.56 \mathrm{~g}$ was separated and washed with a $\mathrm{NaHCO}_{3}$ solution and a saturated $\mathrm{NaCl}$ solution, dried over $\mathrm{Na}_{2} \mathrm{SO}_{4}$, after which the enriched extract was chromatographed on a column with silica gel in benzene in an increasing gradient of EA. Fractions containing parthenolide $(\mathbf{X})\left(R_{\mathrm{f}} 0.24\right.$ in benzene/EA 9: 1 on Merck TLC plates; $R_{\mathrm{f}} 0.49$ on Silufol plates) were collected, the solvent was distilled off and evacuated, and the fractions were additionally crystallized from cold ether. The yield of the product was $2.77 \mathrm{~g}$ as a colorless slightly yellow powder. The NMR spectrum of parthenolide $(\mathbf{X})$ is similar to that described earlier [31].

Synthesis of isozaluzanin C (XIV) from dehydrocostus lactone (VIII). In a 500-mL flask, $8.0 \mathrm{~g}$ of dehydrocostus lactone $(\mathbf{X})\left(34.7 \mathrm{mmol}, R_{\mathrm{f}} 0.76\right.$ in benzene/EA $10: 1 ; R_{\mathrm{f}} 0.9$ in benzene/EA $\left.2: 1\right)$ was dissolved in chloroform $(250 \mathrm{~mL})$, selenium dioxide $(1 \mathrm{~g})$ was added, and the mixture was vigorously stirred for 10 min at room temperature. Then, $10 \mathrm{~mL}$ of $70 \%$ $t$ - $\mathrm{BuOOH}$ was added in portions of $1 \mathrm{~mL}$ once per minute, and the mixture was stirred for an additional $2.5 \mathrm{~h}$; the course of the reaction was monitored by TLC. Then, anhydrous $\mathrm{Na}_{2} \mathrm{SO}_{4}$ was added to the reaction mixture, the solvent was evaporated under reduced pressure without heating, the residual $\mathrm{Na}_{2}$ $\mathrm{SO}_{4}$ was washed several times with ethyl acetate and also evaporated, dried under vacuum and applied to a column with silica gel; elution was in an increasing gradient of benzene/EA and then with acetone. Fractions containing lactone (XIV) $\left(R_{\mathrm{f}} 0.11\right.$ in benzene/EA $10: 1 ; R_{\mathrm{f}} 0.43$ in benzene/EA $\left.2: 1\right)$ were additionally purified, if necessary, by rechromatography to isolate from mixed fractions and remove the contaminations of selenium oxide. The yield of the product is $4.76 \mathrm{~g}$ in the form of a white solid substance. The ${ }^{1} \mathrm{H}$ NMR spectrum corresponds to that described earlier [32].

Acylation of isotelekin (V). Isotelekin (V) (4 g, $16.1 \mathrm{mmol})$ was dissolved in a flask in pyridine $(40 \mathrm{~mL})$. Then, acyl chloride ( $1.77 \mathrm{~g})$ was added dropwise under stirring, the flask was closed with a stopper, and the reaction was allowed to proceed overnight at room temperature. After this, the main portion of pyridine was distilled under reduced pressure, water and ether were added to the residue, and the mixture was kept in an ultrasonic bath until the resin dissolved. The water layer was extracted three times with ether after which the sum of organic parts was washed with a solution of tartaric acid and evaporated to obtain 5.05 $\mathrm{g}$ of the residue of crude lactone $(\mathbf{X V})$. The product was purified by column chromatography on silica gel; the fractions with $R_{\mathrm{f}}=0.77$ were collected by TLC in a Chl/acetone system 20:1 (mobility of isotelekin $R_{\mathrm{f}}$ $0.39)$. The yield of the pure acylated product $(\mathbf{X V})$ was $3.55 \mathrm{~g}$ (12.2 mmol, 76.0\%). The ${ }^{1} \mathrm{H}$ NMR spectrum corresponds to that described in the literature [33].

A general method for the addition of thiophenol to sesquiterpene lactones. Method A (standard): $1 \mathrm{mmol}$ lactone was dissolved in methanol $(10 \mathrm{~mL})$ in a vial at room temperature, and $232 \mu \mathrm{L}$ of thiophenol $(2.1 \mathrm{mmol})$ and $100 \mu \mathrm{L}$ of triethylamine were added thereto. After stirring, the vial was closed, insulated by a parafilm layer, and left for three days. The course of the reaction was monitored by TLC. The solvent was distilled under reduced pressure in a water bath $\left(40^{\circ} \mathrm{C}\right)$, the residue was dissolved in chloroform and washed in a funnel successively with a $\mathrm{Na}_{2} \mathrm{CO}_{3}$ solution, water, and a weak $\mathrm{NaCl}$ solution; each time, additional extraction with another portion of chloroform was carried out. The combined organic layers were dried over $\mathrm{Na}_{2} \mathrm{SO}_{4}$, the solvent was distilled and evacuated, and the residue was crystallized with $2 \mathrm{~mL}$ of methanol at $-10^{\circ} \mathrm{C}$; methanol was removed by a pipette and evacuated again. The product was obtained in the form of a light powder.

Method B: 1 mmol lactone was dissolved in methanol $(10 \mathrm{~mL})$ in a vial at room temperature, and $232 \mu \mathrm{L}(2.1 \mathrm{mmol})$ of thiophenol and $100 \mu \mathrm{L}$ of triethylamine were added and stirred. To a rapidly crystallizing reaction mixture, chloroform $(5 \mathrm{~mL})$ was added, and the mixture was allowed to stand for an additional $10 \mathrm{~min}$, after which the solvent was distilled under reduced pressure. The residue was evacuated and crystallized from $5 \mathrm{~mL}$ of cold methanol $\left(-10^{\circ} \mathrm{C}\right)$. Precipitated crystals were rapidly filtered on a glass filter under reduced pressure and dried in vacuum. 
Method C: The reaction mixture was evaporated under reduced pressure, and the residue was immediately chromatographed on a column with silica gel.

Method D: the reaction mixture was treated as in method $\mathrm{A}$, and the residue was chromatographed on a column with silica gel.

Method E: crystals precipitated from the reaction mixture were filtered on a glass filter, and the product that remained in the stock solution was derived as in method A.

$(3 S, 3 \mathrm{a} R, 4 S, 6 \mathrm{a} R, 9 S, 9 \mathrm{a} R, 9 \mathrm{~b} R)-4-H y d r o x y-9-m e t h y l-$ 6-methylen-3-((phenylthio)methyl)octahydroazuleno[4,5b] furan-2,8(3H,4H)-dione (Ia). Large colorless rectangular crystals; TLC $R_{\mathrm{f}}=0.51$ in a chloroform/acetone system $20: 2$.

${ }^{1} \mathrm{H}$ NMR $\left(200 \mathrm{MHz}, \mathrm{CDCl}_{3}\right): 1.23(3 \mathrm{H}, \mathrm{d}, J 6.7$, $\mathrm{H} 15), 2.05\left(1 \mathrm{H}, \mathrm{dd}, J_{1} 12.1, J_{2} 10.2, \mathrm{H} 9 \mathrm{a}\right), 2.25(2 \mathrm{H}$, $\mathrm{m}, \mathrm{H} 4+\mathrm{H} 5), 2.50(1 \mathrm{H}, \mathrm{s}, \mathrm{H} 2 \mathrm{a}), 2.51(1 \mathrm{H}, \mathrm{d}, J 10.7$, $\mathrm{H} 2 \mathrm{~b}), 2.73(2 \mathrm{H}, \mathrm{m}, \mathrm{H} 9 \mathrm{~b}+\mathrm{H} 7), 2.99(2 \mathrm{H}, \mathrm{m}, \mathrm{H} 1+$ $\mathrm{H} 11), 3.42\left(1 \mathrm{H}, \mathrm{dd}, J_{1} 13.8, J_{2} 4.2, \mathrm{H} 13 \mathrm{a}\right), 3.66(1 \mathrm{H}$, $\left.\mathrm{dd}, J_{1} 14.3, J_{2} 4.9, \mathrm{H} 13 \mathrm{~b}\right), 3.70(1 \mathrm{H}, \mathrm{m}, \mathrm{H} 8), 3.93(1 \mathrm{H}$, t, J 9.0, H6), 4.74 (1H, s, H14a), $5.04(1 \mathrm{H}, \mathrm{s}, \mathrm{H} 14 \mathrm{~b})$, 7.20-7.51 $\left(5 \mathrm{H}, \mathrm{Ph}+\mathrm{CHCl}_{3}\right)$.

${ }^{13} \mathrm{C}$ NMR (50 MHz, $\left.\mathrm{CDCl}_{3}\right): 14.4$ (C15), 34.2 (C13), 39.6 (C4), 43.5 (C9), 46.9 (C5), 47.2 (C1), 48.5 (C2), 49.7 (C7), 51.2 (C11), 75.1 (C8), 83.2 (C6), 115.1 (C14), $126.9(\mathrm{Cd}), 129.2(\mathrm{Cc}), 130.2(\mathrm{Cb}), 135.5(\mathrm{Ca})$, 143.6 (C10), 175.8 (C12), 218.8 (C3).

$(3 S, 5$ a $S, 6 R, 8$ a $S, 12 S)-3,6$-Dimethyl-9-((phenylthio)methyl)octahydro-12H-3,12-epoxy $[1,2]$ dioxypino[4,3-i] isochromen-10(3H)-one (IVa). An amorphous substance, TLC in a benzene/EA system $2: 1$, $R_{\mathrm{f}}=0.62$.

${ }^{1} \mathrm{H}$ NMR $\left(200 \mathrm{MHz}, \mathrm{CDCl}_{3}\right): \delta 0.96(3 \mathrm{H}, \mathrm{d}, J 5.5$, H14), $1.46(3 \mathrm{H}, \mathrm{s}, \mathrm{H} 15), 3.17\left(1 \mathrm{H}, \mathrm{dd}, J_{1} 13.7, J_{2} 11.8\right.$, H13a), $3.91\left(1 \mathrm{H}, \mathrm{dd}, J_{1} 13.8, J_{2} 3.3, \mathrm{H} 13 \mathrm{~b}\right), 5.93(1 \mathrm{H}$, s, H5), 7.20-7.42 (5H, $\left.\mathrm{Ph}+\mathrm{CHCl}_{3}\right)$.

${ }^{13} \mathrm{C}$ NMR $\left(50 \mathrm{MHz}, \mathrm{CDCl}_{3}\right): \delta 19.8(\mathrm{C} 14), 24.7$ (C8), 25.4 (C2), 31.3 (C15), 33.8 (C9), 35.8 (C3), 37.6 (C10), 38.0 (C13), 41.1 (C11), 43.4 (C7), 50.3 (C1), 80.7 (C6), 94.0 (C5), 105.4 (C4), 126.5 (Cd), 129.2 (Cc), $129.4(\mathrm{Cb}), 134.5(\mathrm{Ca}), 170.5(\mathrm{C} 12)$.

$(3 R, 3 \mathrm{a} R, 6 R, 8 \mathrm{a} R, 9 \mathrm{a} R)-6-H y d r o x y-8 \mathrm{a}-m e t h y l-5-$ methylene-3-((phenylthio)methyl)decahydronaphtho [2,3b] furan-2(3H)-one (Va). Gray crystals; TLC in a benzene/EA system $9: 1 R_{\mathrm{f}}=0.32$ for the product; $R_{\mathrm{f}}=$ 0.19 for isotelekin.

${ }^{1} \mathrm{H}$ NMR $\left(200 \mathrm{MHz}, \mathrm{CDCl}_{3}\right): \delta 0.80(1 \mathrm{H}, \mathrm{s}, \mathrm{H} 15)$, $1.53\left(1 \mathrm{H}\right.$, dd $\left.J_{1} 15.5, J_{2} 4.5, \mathrm{H} 9 \mathrm{a}\right), 2.17(1 \mathrm{H}, \mathrm{d}, J 15.1$, H9b), 2.39 (1H, br d, J 11.8, H5), $2.63(1 \mathrm{H}, \mathrm{m}, \mathrm{H} 7)$, $2.92(1 \mathrm{H}, \mathrm{d}, J$ 7.1, H11), $3.51(2 \mathrm{H}, \mathrm{m}, \mathrm{H} 13 \mathrm{a}+\mathrm{H} 13 \mathrm{~b})$, $4.33(1 \mathrm{H}$, br s, H3), $4.46(1 \mathrm{H}$, br s, H8), $4.61(1 \mathrm{H}, \mathrm{s}$, H15a), $5.03(1 \mathrm{H}, \mathrm{s}, \mathrm{H} 15 \mathrm{~b}), 7.20-7.54(5 \mathrm{H}, \mathrm{Ph}+$ $\mathrm{CHCl}_{3}$ ).

${ }^{13} \mathrm{C}$ NMR $\left(50 \mathrm{MHz}, \mathrm{CDCl}_{3}\right): \delta 17.0(\mathrm{C} 14), 20.1$ (C6), 29.0 (C13 + C2), 34.7 (C10), 35.8 (C1), 38.5
(C7), 40.4 (C5), 41.1 (C9), 48.6 (C11), 73.3 (C3), 78.2 (C8), 109.9 (C15), 126.8 (Cd), $127.4(\mathrm{Cc}), 129.0(\mathrm{Cb})$, $129.9(\mathrm{Ca}), 150.3(\mathrm{C} 4), 176.9(\mathrm{C} 12)$.

$(3 R, 3 \mathrm{a} R, 4 \mathrm{a} R, 8 \mathrm{a} R, 9 \mathrm{a} R)-4 \mathrm{a}-H y d r o x y-8 \mathrm{a}-m e t h y l-$ 5-methylen-3-((phenylthio)methyl)decahydronaphtho[2,3-b]furan-2(3H)-one (VIa). Yield $481 \mathrm{mg}(67.1 \%)$ in total when calculating the reaction for $2 \mathrm{mmol} \mathrm{lac}$ tone (VI). Large crystals.

${ }^{1} \mathrm{H}$ NMR $\left(200 \mathrm{MHz}, \mathrm{CDCl}_{3}\right): \delta 0.93(3 \mathrm{H}, \mathrm{s}, \mathrm{H} 14)$, $1.14(1 \mathrm{H}$, br s, H1a), $1.60(2 \mathrm{H}, \mathrm{m}, \mathrm{H} 2 \mathrm{a}+\mathrm{H} 2 \mathrm{~b}), 1.86$ $\left(1 \mathrm{H}, \mathrm{dd}, J_{1} 15.4, J_{2} 2.4\right.$, H6a), $2.15\left(1 \mathrm{H}, \mathrm{dt}, J_{1} 13.7, J_{2}\right.$ 3.5, H3a), $2.56(2 \mathrm{H}, \mathrm{m}, \mathrm{H} 3 \mathrm{~b}+\mathrm{H} 7), 2.92(2 \mathrm{H}, \mathrm{m}$, $\mathrm{H} 13 \mathrm{a}+\mathrm{H} 11), 3.52(1 \mathrm{H}, \mathrm{d}, J 9.7, \mathrm{H} 13 \mathrm{~b}), 4.51(1 \mathrm{H}, \mathrm{br}$ s, H8), 4.68 (1H, s, H15a), 4.87 (1H, s, H15b), 7.20$7.44\left(5 \mathrm{H}, \mathrm{Ph}+\mathrm{CHCl}_{3}\right)$.

${ }^{13} \mathrm{C}$ NMR $\left(50 \mathrm{MHz}, \mathrm{CDCl}_{3}\right): \delta 21.5(\mathrm{C} 2), 21.6$ (C14), 26.7 (C6), 29.3 (C13), 31.6 (C3), 35.2 (C7), 35.3 (C1), 35.7 (C9), 36.9 (C10), 46.3 (C11), 74.2 (C5), 78.3 (C8), 108.8 (C15), 126.9 (Cd), 129.2 (Cc), $130.3(\mathrm{Cb}), 135.6(\mathrm{Ca}), 150.5(\mathrm{C} 4), 177.0(\mathrm{C} 12)$.

$(3 R, 3 \mathrm{a} R, 4 \mathrm{a} S, 6 R, 8 \mathrm{a} R, 9 \mathrm{a} R)-4 \mathrm{a}, 6-D i h y d r o x y-8 \mathrm{a}-$ methyl-5-methylene-3-((phenylthio)methyl)decahydronaphtho[2,3-b]furan-2(3H)-one (VIIa). A white amorphous solid substance; TLC in a benzene/EA system $2: 1 R_{\mathrm{f}}=0.67$.

${ }^{1} \mathrm{H}$ NMR $\left(200 \mathrm{MHz}, \mathrm{CDCl}_{3}\right): \delta 0.82(3 \mathrm{H}, \mathrm{s}, \mathrm{H} 14)$, $1.04\left(1 \mathrm{H}, \mathrm{dd} J_{1} 13.2, J_{2} 4.1, \mathrm{H} 1 \mathrm{a}\right), 2.90\left(1 \mathrm{H}, \mathrm{dd}, J_{1} 6.1\right.$, $\left.J_{2} 2.3, \mathrm{H} 11\right), 3.11\left(1 \mathrm{H}, \mathrm{dd}, J_{1} 12.3, J_{2} 2.4, \mathrm{H} 13 \mathrm{a}\right), 3.43$ $\left(1 \mathrm{H}, \mathrm{dd}, J_{1} 12.3, J_{2} 4.9, \mathrm{H} 13 \mathrm{~b}\right), 4.32(1 \mathrm{H}, \mathrm{br} \mathrm{s}, \mathrm{H} 3)$, $4.43(1 \mathrm{H}, \mathrm{t}, J 4.2, \mathrm{H} 8), 4.83(1 \mathrm{H}, \mathrm{s}, \mathrm{H} 15 \mathrm{a}), 5.04(1 \mathrm{H}$, s, $\mathrm{H} 15 b), 7.14-7.31\left(5 \mathrm{H}, \mathrm{Ph}+\mathrm{CHCl}_{3}\right)$.

${ }^{13} \mathrm{C}$ NMR (50 MHz, $\left.\mathrm{CDCl}_{3}\right): \delta 21.4(\mathrm{C} 14), 26.0$ (C1), 28.4 (C2), 29.4 (C13), 30.1 (C6), 34.8 (C10), 35.6 (C9), 37.2 (C7), 46.0 (C11), 74.9 (C3), 75.5 (C5), 78.3 (C8), 112.9 (C15), 126.9 (Cd), 129.3 (Cc), 129.7 (Cb), 130.8 (Ca), 148.3 (C4), 176.9 (C12).

(3S,3aS,6aR,9a R,9bS)-6,9-Dimethylen-3-((phenylthio)methyl)decahydroazuleno [4,5-b]furan-2(3H)one (VIIIa). Needles of methanol or a solid white substance.

${ }^{1} \mathrm{H}$ NMR $\left(200 \mathrm{MHz}, \mathrm{CDCl}_{3}\right): \delta 2.83(1 \mathrm{H}, \mathrm{m}, \mathrm{H} 5)$, $3.15\left(1 \mathrm{H}, \mathrm{dd}, J_{1} 13.8, J_{2} 6.8, \mathrm{H} 13 \mathrm{a}\right), 3.55\left(1 \mathrm{H}, \mathrm{dd}, J_{1}\right.$ $\left.13.6, J_{2} 4.1, \mathrm{H} 13 \mathrm{~b}\right), 3.92(1 \mathrm{H}, \mathrm{t}, J 8.8, \mathrm{H} 6), 4.76(1 \mathrm{H}$, s, H14a), $4.84(1 \mathrm{H}, \mathrm{s}, \mathrm{H} 14 \mathrm{~b}), 5.06(1 \mathrm{H}, \mathrm{br} \mathrm{s}, \mathrm{H} 15 \mathrm{a})$, $5.20\left(1 \mathrm{H}\right.$, br s, H15b), 7.20-7.54 (5H, $\left.\mathrm{Ph}+\mathrm{CHCl}_{3}\right)$.

${ }^{13} \mathrm{C}$ NMR (50 $\left.\mathrm{MHz}, \mathrm{CDCl}_{3}\right): \delta 30.1 \quad(\mathrm{C} 2)$, 32.5(C8), 32.9 (C9), 33.4 (C3), 37.2 (C13), 46.8 (C1), 46.9 (C7), 47.1 (C11), 52.0 (C5), 85.2 (C6), 109.3 (C14), 112.0 (C15), 126.6 (Cd), 127.5 (Cc), 129.0 (Cb), 135.6 (Ca), 137.0 (C10), 149.6 (C4), 176.3 (C12).

$(3 S, 3 \mathrm{a} S, 5 \mathrm{a} R, 6 R, 9 \mathrm{~b} S)$-6-Hydroxy-5a,9-dimethyl3-((phenylthio)methyl)-3a,4,5,5a,6,7,9a,9b-octahydronaphtho[1,2-b]furan-2(3H)-one (IXa). Oil. TLC in a benzene/EA system $10: 1 R_{\mathrm{f}}=0.23$. 
${ }^{1} \mathrm{H}$ NMR $\left(200 \mathrm{MHz}, \mathrm{CDCl}_{3}\right): \delta 0.86(3 \mathrm{H}, \mathrm{s}, \mathrm{H} 14)$, $1.17(1 \mathrm{H}, \mathrm{m}, \mathrm{H} 9 \mathrm{a}), 1.80(3 \mathrm{H}, \mathrm{s}, \mathrm{H} 15), 2.07(1 \mathrm{H}, \mathrm{m}$, H8a), 2.43 (1H, m, H7), 2.58 (1 H, ddd, $J_{1} 12.6, J_{2} 8.1$, $\left.\mathrm{J}_{3} 3.7, \mathrm{H} 11\right), 3.03\left(1 \mathrm{H}, \mathrm{dd}, J_{1} 13.7, J_{2} 8.1, \mathrm{H} 13 \mathrm{a}\right), 3.57$ $\left(1 \mathrm{H}, \mathrm{dd}, J_{1} 13.6, J_{2} 3.7, \mathrm{H} 13 \mathrm{~b}\right), 3.67\left(1 \mathrm{H}, \mathrm{dd}, J_{1} 10.0\right.$, $\left.J_{2} 6.7, \mathrm{H} 1\right), 3.93\left(1 \mathrm{H}, \mathrm{dd}, J_{1} 11.4, J_{2} 10.0, \mathrm{H} 6\right), 5.34$ $\left(1 \mathrm{H}\right.$, br s, H3), $7.20-7.45\left(5 \mathrm{H}, \mathrm{Ph}+\mathrm{CHCl}_{3}\right.$.

${ }^{13} \mathrm{C}$ NMR $\left(50 \mathrm{MHz}, \mathrm{CDCl}_{3}\right): \delta 11.0(\mathrm{C} 14), 23.3$ (C8), 23.6 (C15), 32.7 (C2), 33.0 (C13), 34.5 (C9), 40.5 (C10), 45.4 (C7), 50.5 (C11), 52.0 (C5), 75.2 (C1), 81.1 (C6), 121.3 (C3), $126.6(\mathrm{Cd}), 129.1$ (Cc), $129.6(\mathrm{Cb}), 133.4(\mathrm{C} 4), 135.6(\mathrm{Ca}), 176.96(\mathrm{C} 12)$.

(3S,3a $S, 9 \mathrm{a} R, 10 \mathrm{a} R, 10 \mathrm{~b} S, Z)-6,9 \mathrm{a}-D i m e t h y l-3-$ ((phenylthio)methyl)-3a,4,5,8,9,9a,10a,10b-octahydrooxyreno $\left[2,3^{\prime}: 9,10\right]$ cyclodeca[1,2-b]furan-2(3H)one (Xa). Yield $411 \mathrm{mg}(76.4 \%)$ when calculating the reaction for $1.5 \mathrm{mmol}$ lactone $(\mathbf{X})$. Slowly crystallizing oil; TLC in a benzene/EA system 9: $1 R_{\mathrm{f}}=0.36$.

${ }^{1} \mathrm{H}$ NMR $\left(200 \mathrm{MHz}, \mathrm{CDCl}_{3}\right): \delta 1.31(3 \mathrm{H}, \mathrm{s}, \mathrm{H} 15)$, $1.69(3 \mathrm{H}, \mathrm{s}, \mathrm{H} 14), 2.36\left(1 \mathrm{H}, \mathrm{ddd}, J_{1} 12.1, J_{2} 6.8, J_{3} 4.3\right.$, H11), $2.72(1 \mathrm{H}, \mathrm{d}, J 9.0, \mathrm{H} 5), 3.32\left(1 \mathrm{H}, \mathrm{dd}, J_{1} 14.1, J_{2}\right.$ 5.4, H13a), 3.51 (1H, dd, $\left.J_{1} 14.2, J_{2} 4.2, \mathrm{H} 13 \mathrm{~b}\right), 3.84$ $(1 \mathrm{H}, \mathrm{t}, J 9.0, \mathrm{H} 6), 5.08\left(1 \mathrm{H}, \mathrm{dd}, J_{1} 12.0, J_{2} 2.1, \mathrm{H} 2\right)$, 7.23-7.52 (5H, $\left.\mathrm{Ph}+\mathrm{CHCl}_{3}\right)$.

${ }^{13} \mathrm{C}$ NMR $\left(50 \mathrm{MHz}, \mathrm{CDCl}_{3}\right): \delta 16.9(\mathrm{C} 14), 17.1$ (C15), 24.0 (C2), 30.1 (C8), 32.9 (C13), 36.5 (C3), 40.5 (C9), 47.7 (C7), 47.9 (C-11), 61.5 (C4), 66.4 (C5), 82.3 (C6), 124.9 (Cd), 128.8 (C1), 129.2 (Cc), 130.0 (Cb), 134.4 (C10), 135.8 (Ca), 175.1 (C12).

$(1 \mathrm{a} R, 2 S, 5 \mathrm{a} R, 6 \mathrm{a} R, 9 R, 9 \mathrm{a} R, 9 \mathrm{~b} S)-2,5 \mathrm{a}-D i m e t h y l-9-$ ((phenylthio)methyl)octahydro- $2 H$-oxyreno[2',3':4,4a]naphtho[2,3-b]furan-8(9H)-one (XIa). White powder. TLC in a benzene/EA system $9: 1 R_{\mathrm{f}}=0.67$.

${ }^{1} \mathrm{H}$ NMR $\left(200 \mathrm{MHz}, \mathrm{CDCl}_{3}\right): \delta 1.10(3 \mathrm{H}, \mathrm{d}, \mathrm{J} 7.6$, $\mathrm{H} 15), 1.21(3 \mathrm{H}, \mathrm{s}, \mathrm{H} 14), 1.41-1.58(5 \mathrm{H}, \mathrm{m}, \mathrm{H} 3+\mathrm{H} 4$ $+\mathrm{H} 2 \mathrm{~b}+\mathrm{H} 9 \mathrm{~b}), 1.60\left(1 \mathrm{H}, \mathrm{dd}, J_{1} 14.8, J_{2} 2.8, \mathrm{H} 1 \mathrm{a}\right), 1.83$ $(3 \mathrm{H}, \mathrm{m}, \mathrm{H} 2 \mathrm{a}+\mathrm{H} 1 \mathrm{~b}+\mathrm{H} 9 \mathrm{~b}), 2.92(1 \mathrm{H}, \mathrm{t}, J 12.2, \mathrm{H} 11)$, $3.07\left(1 \mathrm{H}, \mathrm{dd}, J_{1} 10.0, J_{2} 2.8, \mathrm{H} 7\right), 3.16(1 \mathrm{H}, \mathrm{s}, \mathrm{H} 6)$, $3.20(1 \mathrm{H}, \mathrm{m}, \mathrm{H} 13 \mathrm{a}), 3.69\left(1 \mathrm{H}, \mathrm{dd}, J_{1} 12.9, J_{2} 2.6\right.$, $\mathrm{H} 13 \mathrm{~b}), 4.58\left(1 \mathrm{H}, \mathrm{dt}, J_{1} 6.2, \mathrm{~J}_{2} 2.9, \mathrm{H} 8\right), 7.23-7.46$ $\left(5 \mathrm{H}, \mathrm{Ph}+\mathrm{CHCl}_{3}\right)$.

${ }^{13} \mathrm{C}$ NMR (50 MHz, $\left.\mathrm{CDCl}_{3}\right): \delta 16.5(\mathrm{C} 2), 17.8$ (C15), 24.1 (C14), 29.6 (C3), 30.8 (C13), 32.1 (C10), 35.3 (C9), 37.8 (C4 + C7), 38.7 (C1), 41.8 (C11), 56.8 (C6), 68.4 (C5), 75.9 (C8), 127.2 (Cd), 129.3 (Cc), $130.3(\mathrm{Cb}), 134.1(\mathrm{Ca}), 176.1(\mathrm{C} 12)$.

$(3 R, 3 \mathrm{a} R, 8 \mathrm{a} R, 9 \mathrm{a} R)-5,8 \mathrm{a}-$ Dimethyl-3-((phenylthio)methyl)-3a, 7,8,8a,9,9a-hexahydronaphtho[2,3-b]furan2(3H)-one (XIIa). Light powder; TLC $R_{\mathrm{f}}=0.86$ in a benzene/EA system $9: 1$.

${ }^{1} \mathrm{H}$ NMR $\left(200 \mathrm{MHz}, \mathrm{CDCl}_{3}\right): \delta 1.08(3 \mathrm{H}, \mathrm{s}, \mathrm{H} 14)$, $1.40(1 \mathrm{H}, \mathrm{m}, \mathrm{H} 1 \mathrm{a}), 1.52(1 \mathrm{H}, \mathrm{d}, J 3.4, \mathrm{H} 1 \mathrm{~b}), 1.59(1 \mathrm{H}$, d, J 2.4, H9a), $1.75(3 \mathrm{H}, \mathrm{s}, \mathrm{H} 15), 2.09(1 \mathrm{H}, \mathrm{m}, \mathrm{H} 2 \mathrm{a})$, $2.22\left(2 \mathrm{H}, \mathrm{dd}, J_{1} 14.9, J_{2} 3.0, \mathrm{H} 2 \mathrm{~b}+\mathrm{H} 9 \mathrm{~b}\right), 2.91(1 \mathrm{H}, \mathrm{t}$,
$J 12.2, \mathrm{H} 11), 3.06\left(1 \mathrm{H}, \mathrm{ddd}, J_{1} 14.6, J_{2} 9.0, J_{3} 4.8, \mathrm{H} 7\right)$, $3.38(1 \mathrm{H}, \mathrm{m}, \mathrm{H} 13 \mathrm{a}), 3.58\left(1 \mathrm{H}, \mathrm{dd}, J_{1} 12.5, J_{2} 2.6\right.$, $\mathrm{H} 13 \mathrm{~b}), 4.78\left(1 \mathrm{H}, \mathrm{dt}, J_{1} 5.5, J_{2} 2.7, \mathrm{H} 8\right), 5.47(1 \mathrm{H}, \mathrm{d}, J$ 3.2, H6), $5.63(1 \mathrm{H}$, br s, H3), $7.21-7.53(5 \mathrm{H}, \mathrm{Ph}+$ $\mathrm{CHCl}_{3}$ ).

${ }^{13} \mathrm{C}$ NMR $\left(50 \mathrm{MHz}, \mathrm{CDCl}_{3}\right): \delta 20.1(\mathrm{C} 15), 22.2$ (C2), 24.7 (C14), 30.6 (C13), 30.8 (C10), 37.2 (C7), 37.7 (C1), 39.5 (C9), 45.4 (C11), 69.1 (C8), 112.6 (C6), $124.6(\mathrm{Cd}), 126.9(\mathrm{C} 3), 129.2(\mathrm{Cc}), 130.2(\mathrm{Cb})$, 130.5 (C4), 137.0 (Ca), 145.2 (C5), 176.4 (C12).

$(3 R, 3 \mathrm{a} S, 4 S, 4 \mathrm{a} R, 5 S, 9 \mathrm{a} R)-4-H y d r o x y-4 a, 5-d i m e t h y l-$ 3-((phenylthio)methyl)-3a, 4,4a,5,6,7,9,9a-octahydronaphtho[2,3-b]furan-2(3H)-one (XIIIa). A solid white substance; TLC $R_{\mathrm{f}}=0.34$ in a benzene/EA system $9: 1$.

${ }^{1} \mathrm{H}$ NMR $\left(200 \mathrm{MHz}, \mathrm{CDCl}_{3}\right): \delta 0.84(3 \mathrm{H}, \mathrm{s}, \mathrm{H}-$ 14), 0.89 (3H, d, J 6.8, H-15), 1.38-1.48 (2H, m, H3), $1.93-2.06(3 \mathrm{H}, \mathrm{m}, \mathrm{H} 2+\mathrm{H} 4), 2.24(1 \mathrm{H}$, br t, $J 12.2$, H9a), $2.60\left(1 \mathrm{H}, \mathrm{dd}, J_{1} 14.0, J_{2} 7.2, \mathrm{H} 9 \mathrm{~b}\right), 2.71(1 \mathrm{H}, \mathrm{m}$, H7), $3.02(1 \mathrm{H}, \mathrm{t}, J 9.0, \mathrm{H} 11), 3.21(1 \mathrm{H}, \mathrm{m}, \mathrm{H} 13 \mathrm{a}), 3.68$ $\left(1 \mathrm{H}, \mathrm{dd}, J_{1} 12.5, J_{2} 2.4, \mathrm{H} 13 \mathrm{~b}\right), 4.08\left(1 \mathrm{H}, \mathrm{dd}, J_{1} 6.0, J_{2}\right.$ 4.4, H6), $4.68\left(1 \mathrm{H}, \mathrm{dt}, J_{1} 10.7, J_{2} 7.4, \mathrm{H} 8\right), 5.66(1 \mathrm{H}$, $\left.\mathrm{dt}, J_{1} 4.7, J_{2} 2.3, \mathrm{H} 1\right), 7.23-7.52\left(5 \mathrm{H}, \mathrm{Ph}+\mathrm{CHCl}_{3}\right)$.

${ }^{13} \mathrm{C}$ NMR $\left(50 \mathrm{MHz}, \mathrm{CDCl}_{3}\right): \delta 16.0(\mathrm{C} 15), 18.8$ (C14), 25.6 (C2), 26.6 (C3), 32.6 (C4), 34.9 (C13), 35.3 (C9), 41.7 (C7), 41.9 (C5), 48.0 (C11), 73.7 (C6), 76.4 (C8), 127.1 (Cd), 128.0 (C1), 129.2 (Cc), 129.3 (Cb), 134.6 (Ca), 135.0 (C10), 176.9 (C12).

(3S,3aS,6aR,8R,9aR,9bS)-8-Hydroxy-6,9-dimethylen-3-((phenylthio)methyl)decaazuleno[4,5-b]furan2(3H)-one (XIVa). Colorless oil. TLC $R_{\mathrm{f}}=0.58$ in a benzene/EA system $2: 1$.

${ }^{1} \mathrm{H}$ NMR $\left(200 \mathrm{MHz}, \mathrm{CDCl}_{3}\right): \delta 3.03(2 \mathrm{H}, \mathrm{m}, \mathrm{H1}+$ $\mathrm{H} 5), 3.15\left(1 \mathrm{H}, \mathrm{dd}, J_{1} 13.8, J_{2} 6.8, \mathrm{H} 13 \mathrm{a}\right), 3.52(1 \mathrm{H}, \mathrm{dd}$, $\left.J_{1} 13.8, J_{2} 4.0, \mathrm{H} 13 \mathrm{~b}\right), 3.87(1 \mathrm{H}, \mathrm{t}, J 9.2, \mathrm{H} 6), 4.67$ $(1 \mathrm{H}$, br s, H3), $4.74(1 \mathrm{H}, \mathrm{s}, \mathrm{H} 14 \mathrm{a}), 4.88(1 \mathrm{H}, \mathrm{s}, \mathrm{H} 14 \mathrm{~b})$, $5.35(1 \mathrm{H}, \mathrm{s}, \mathrm{H} 15 \mathrm{a}), 5.44(1 \mathrm{H}, \mathrm{s}, \mathrm{H} 15 \mathrm{~b}), 7.22-7.43$ $\left(5 \mathrm{H}, \mathrm{Ph}+\mathrm{CHCl}_{3}\right)$.

${ }^{13} \mathrm{C}$ NMR $\left(50 \mathrm{MHz}, \mathrm{CDCl}_{3}\right): \delta 32.9$ (C8), 33.3 (C9), 37.5 (C13), 39.7 (C2), 43.8 (C1), 46.7 (C7), 47.3 (C11), 49.5 (C5), 74.5 (C3), 84.8 (C6), 112.6 (C14), 112.9 (C15), $126.7(\mathrm{Cd}), 129.2(\mathrm{Cc}), 129.7(\mathrm{Cb}), 135.5$ (Ca), 148.9 (C10), 154.3 (C4), 176.1 (C12).

$(3 R, 3 \mathrm{a} R, 6 R, 8 \mathrm{a} R, 9 \mathrm{a} R)-8 \mathrm{a}-M e t h y l-5-m e t h y l e n-2-$ oxy-3-((phenylthio)methyl)dodecanaphtho[2,3-b]furan6-yl acetate (XVa). A low-melting white substance.

${ }^{1} \mathrm{H}$ NMR $\left(200 \mathrm{MHz}, \mathrm{CDCl}_{3}\right): \delta 0.82(3 \mathrm{H}, \mathrm{s}, \mathrm{H} 14)$, $1.14(1 \mathrm{H}, \mathrm{d}, \mathrm{J} 12.6, \mathrm{H} 1 \mathrm{a}), 1.39\left(1 \mathrm{H}, \mathrm{dt}, J_{1} 12.7, J_{2} 3.5\right.$, $\mathrm{H} 1 \mathrm{~b}), 1.53\left(1 \mathrm{H}, \mathrm{dd}, J_{1} 10.4, J_{2} 4.5, \mathrm{H} 6 \mathrm{a}\right), 1.59(1 \mathrm{H}, \mathrm{br}$ s, H9a), $1.68\left(1 \mathrm{H}, \mathrm{dd}, J_{1} 10.6, J_{2} 5.0, \mathrm{H} 6 \mathrm{~b}\right), 1.81(2 \mathrm{H}$, $\mathrm{m}, \mathrm{H} 5+\mathrm{H} 2 \mathrm{a}), 2.08(3 \mathrm{H}, \mathrm{s}, \mathrm{MeCOO} 3), 2.20(2 \mathrm{H}, \mathrm{m}$, $\mathrm{H} 9 \mathrm{~b}+\mathrm{H} 2 \mathrm{~b}), 2.65\left(1 \mathrm{H}, \mathrm{dd}, J_{1} 11.6, J_{2} 5.6, \mathrm{H} 11\right), 2.91$ $(2 \mathrm{H}, \mathrm{m}, \mathrm{H} 7+\mathrm{H} 13 \mathrm{a}), 3.52(1 \mathrm{H}, \mathrm{m}, \mathrm{H} 13 \mathrm{~b}), 4.47(1 \mathrm{H}$, dd, $\left.J_{1} 5.5, J_{2} 3.6, \mathrm{H} 8\right), 4.74(1 \mathrm{H}$, br s, H15a), $5.15(1 \mathrm{H}$, 
br s, H15b), $5.37(1 \mathrm{H}, \mathrm{t}, J 2.8, \mathrm{H} 3), 7.20-7.40(5 \mathrm{H}$, $\left.\mathrm{Ph}+\mathrm{CHCl}_{3}\right)$.

${ }^{13} \mathrm{C}$ NMR $\left(50 \mathrm{MHz}, \mathrm{CDCl}_{3}\right): \delta 17.2(\mathrm{C} 14), 20.0$ (C6), $21.52\left(\mathrm{MeCOO}_{3}\right), 27.0$ (C2), 29.0 (C13), 34.4 (C10), 36.4 (C1), 38.5 (C7), 41.1 (C9), 41.7 (C5), 46.6 (C11), 75.2 (C3), 78.0 (C8), 112.5 (C15), 126.84 (Cd), $127.1(\mathrm{Cc}), 127.5\left(\mathrm{Cc}^{\prime}\right), 129.0(\mathrm{Cb}), 129.2\left(\mathrm{Cb}^{\prime}\right), 129.9$ (Ca), 145.65 (C4), 170.0 (MeOO3), 176.67 (C12).

Cell cultures. Human cell cultures: RD (rhabdomyosarcoma, ATCC ${ }^{\circledR}$ CCL-136 ${ }^{\mathrm{TM}}$ ), HCT116 (intestinal carcinoma, ATCC ${ }^{\circledR}$ CCL-247 ${ }^{\mathrm{TM}}$ ), HeLa (adenocarcinoma of the cervix, $\left.\mathrm{ATCC}^{\circledR}{ }^{\circledR} \mathrm{CCL}^{2}{ }^{\mathrm{TM}}\right), \mathrm{A} 549$ (lung carcinoma, ATCC $^{\circledR}$ CCL-185 ${ }^{\mathrm{TM}}$ ), and HEK293 (ATCC $^{\circledR}$ CCL-1573 ${ }^{\mathrm{TM}}$ ) were grown in medium DMEM (for A549, HCT116, and RD) and EMEM (for HeLa) supplemented with $10 \%$ fetal calf serum, $2 \mathrm{mM}$ L-glutamine, and $1 \%$ gentamycin as an antibiotic at $37^{\circ} \mathrm{C}$ and $5 \% \mathrm{CO}_{2}$ in a humid atmosphere. Initial cell cultures were obtained from the collection of the Institute of Cytology, Russian Academy of Sciences (St. Petersburg, Russia).

Cytotoxicity in vitro. The cytotoxicity of the compounds synthesized was determined using the MTT test. Cells were seeded at a concentration of $1 \times 10^{4}$ cells per $200 \mu \mathrm{L}$ in a $96-$ well plate and cultured at $37^{\circ} \mathrm{C}$ in a humid atmosphere with $5 \% \mathrm{CO}_{2}$. After $24 \mathrm{~h}$ of incubation, test compounds at different concentrations $(100-1.56 \mu \mathrm{M})$ were added to cell cultures, and the cells were cultured under the same conditions for $72 \mathrm{~h}$. The experiment was carried out in triplicate for each concentration. All compounds were dissolved in DMSO; the final concentration of DMSO in a well was not higher than $0.1 \%$ and was not toxic to cells. Wells to which the solvent at a final concentration of no higher than $0.1 \%$ was added served as a control. After incubation, $20 \mu \mathrm{L}$ of MTT (3-(4,5-dimethylthiazol-2yl)-2,5-diphenyl-tetrazolium bromide, $5 \mathrm{mg} / \mathrm{mL}$ ) was added to each well, and the plates were incubated for an additional $2 \mathrm{~h}$. Then, the medium was removed from plates, and DMSO $(100 \mu \mathrm{L})$ was added to each well to dissolve the resulting formazan crystals. Using a Victor ${ }^{3}$ plate analyzer (PerkinElmer, United States), the optical density at $530 \mathrm{~nm}$ minus the measured background absorbance at $620 \mathrm{~nm}$ was determined. The concentration that induces a $50 \%$ inhibition of the growth of a cell population $\left(\mathrm{IC}_{50}\right)$ was determined from dose-response curves using the OriginPro 9.0 software (PerkinElmer, United States).

\section{CONCLUSIONS}

Many members of the class of sesquiterpene lactones exhibit pronounced cytotoxic activity and are promising antitumor agents. At the same time, an urgent problem is to increase the selectivity of their action toward tumor cells. For this purpose, we synthesized a series of conjugates of SLs with thiophenol by the Michael reaction. The conjugates of this type are capable of oxidation at the sulfur atom under the action of intracellular ROS followed by the retroelimination of the Michael addition product, which leads to the release of active SL. The data on the cytotoxic activity of the resulting prodrug conjugates indicate that, as a rule, they possess, quite expectedly, the activity that is several times lower than that of the parent lactone; but, what is more important, they still demonstrate cytotoxicity toward the tested cell lines. This favors the feasibility of using this approach for the creation of SL prodrugs. It could be assumed that the decrease in the cytotoxicity of conjugates would be proportional for all SLs and would depend only on the type of the cell line; however, this is not the case; different lactones show different degrees of decrease in cytotoxicity. Among the tested compounds, the conjugates of alantolactone (IIa) and artemisitene (IVa) merit attention as promising agents for further optimization.

This approach to the design of SL prodrugs makes it possible in the future to use substituted thiophenols to impart a required lipophilicity to the conjugate molecule as a whole without interfering with the structure of an SL or to attach an SL residue to vector molecules for more selective delivery into the tumor tissue.

\section{FUNDING}

The work was supported by the Russian Foundation for Basic Research (project no. 18-33-00567 mol_a). Analysis of NMR spectra was performed under the support of State Program 0090_2019_0006.

\section{COMPLIANCE WITH ETHICAL STANDARDS}

The article does not contain any studies involving animal or human participants performed by any of the authors.

\section{Conflict of Interests}

The authors declare that there is no conflict of interest.

\section{OPEN ACCESS}

This article is licensed under a Creative Commons Attribution 4.0 International License, which permits use, sharing, adaptation, distribution and reproduction in any medium or format, as long as you give appropriate credit to the original author(s) and the source, provide a link to the Creative Commons licence, and indicate if changes were made. The images or other third party material in this article are included in the article's Creative Commons licence, unless indicated otherwise in a credit line to the material. If material is not included in the article's Creative Commons licence and your intended use is not permitted by statutory regulation or exceeds the permitted use, you will need to obtain permission directly from the copyright holder. To view a copy of this licence, visit http://creativecommons.org/licenses/by/4.0/. 


\section{REFERENCES}

1. Zhang, S., Won, Y.-K., Ong, C.-N., and Shen, H.-M., Curr. Med. Chem. Anticancer Agents, 2005, vol. 5, pp. 239-249. https://doi.org/10.2174/1568011053765976

2. Pickman, A.K., Biochem. System. Ecol., 1986, vol. 14, pp. 255-281.

https://doi.org/10.1016/0305-1978(86)90101-8

3. Siedle, B., Garcia-Pineres, A.J., Murillo, R., SchulteMonting, J., Castro, V., Rungeler, P., Klaas, C.A., Da, CostaF.B., Kisiel, W., and Merfort, I., J. Med. Chem., 2004, vol. 47, pp. 6042-6054. https://doi.org/10.1021/jm049937r

4. Gaspar, A.R., Potgieter, D.J., and Vermeulen, N.M., Biochem. Pharmacol., 1986, vol. 35, pp. 493-497. https://doi.org/10.1016/0006-2952(86)90225-X

5. Iwai, K., Kosugi, H., and Uda, H., Chem. Lett., 1974, vol. 3, pp. 1237-1240. https://doi.org/10.1246/cl.1974.1237

6. Trost, B.M., Salzmann, T.N., and Hiroi, K., J. Am. Chem. Soc., 1976, vol. 98, pp. 4887-4902.

https://doi.org/10.1021/ja00432a034

7. Brownbridge, P. and Warren, S., J. Chem. Soc., Chem. Commun., 1977, vol. 13, pp. 465-466. https://doi.org/10.1039/C39770000465

8. Doskey, C.M., Buranasudja, V., Wagner, B.A., Wilkes, J.G., Du, J., Cullen, J.J., and Buettner, G.R., Redox Biol., 2016, vol. 10, pp. 274-284.

https://doi.org/10.1016/j.redox.2016.10.010

9. Fardella, G., Barbetty, P., Grandolini, G., Chiappini, I., Ambrogi, V., Scarcia, V., and Candiani, A.F., Eur. J. Med. Chem., 1999, vol. 34, pp. 515-523.

https://doi.org/10.1016/S0223-5234(99)80100-7

10. Schaeffer, M., Stampf, J.-L., and Benezra, C., Org. Chem., 1989, vol. 54, pp. 6106-6113. https://doi.org/10.1021/jo00287a024

11. Corbet, J.-P. and Benezra, C., Can. J. Chem., 1979, vol. 57, pp. 213-217.

https://doi.org/10.1139/v79-034

12. Paitayatat, S., Tarnchompoo, B., Thebtaranonth, Y., and Yuthavong, Y., J. Med. Chem., 1997, vol. 40, pp. 633-638.

https://doi.org/10.1021/jm960767v

13. Fischer, N.H., Olivier, E.J., and Fischer, H.D., in Fortschritte der Chemie organischer Naturstoffe (Progress in the Chemistry of Organic Natural Products), Herz, W., Grisebach, H., and Kirby, G.W., Eds., Vienna: Springer, 1979, vol. 38, pp. 47-320.

14. Buděšinsky, M. and Šaman, D., Ann. Rep. NMR Spectr., 1995, vol. 30, pp. 231-475. https://doi.org/10.1016/S0066-4103(08)60027-7

15. Klochkov, S.G., Afanas'eva, S.V., and Zefirov, N.S., Tekhn. Zhivykh Sist., 2008, vol. 5, pp. 31-39.

16. Rekha, R., Chemical transformations of sesquiterpene lactones by conventional and non-conventional methodologies and their evaluation as agrochemicals, Thesis, Ludhiana: Punjab Agricult. Univ., 2006.

17. Semakov, A.V. and Klochkov, S.G., KhRS, 2020, vol. 3, pp. 145-154.

https://doi.org/10.14258/jcprm.2020034681
18. Brossi, A., Venugopalan, B., Gerpe, L.D., Yeh, H.J.C., Flippen-Anderson, J.L., Buchs, P., Luo, X.D., Milhous, W., and Peters, W., J. Med. Chem., 1988, vol. 31, pp. 645-650.

https://doi.org/10.1021/jm00398a026

19. El-Feraly, F.S., Ayalp, A., Al-Yahya, M.A., McPhail, D.R., and McPhail, A.T., J. Nat. Prod., 1990, vol. 53, pp. 66-71. https://doi.org/10.1021/np50067a008

20. Zuma, N.H., Smit, F.J., de Kock, C., Combrinck, J., Smith, P.J., and N'Da, D.D., Eur. J. Med. Chem., 2016, vol. 122, pp. 635-646. https://doi.org/10.1016/j.ejmech.2016.07.027

21. Klochkov, S.G., Afanas'eva, S.V., and Pushin, A.N., Chem. Nat. Comp., 2006, vol. 42, pp. 400-406.

https://doi.org/10.1007/s10600-006-0166-7

22. Artemova, N.P., Nikitina, L.E., Yushkov, D.A., Shigabutdinova, O.G., Plemenkov, V.V., Klochkov, V.V., and Khairutdinov, B.I., Chem. Nat. Comp., 2005, vol. 41, pp. 45-47.

https://doi.org/10.1007/s10600-005-0071-5

23. Ginanneschi, M., Chelli, M., Papini, A.M., Pinzani, D., and Rapi, G., Magnet. Res. Chem., 1996, vol. 34, pp. 95-99.

https://doi.org/10.1002/(SICI)1097-458X(199602)34: 2<95::AID-OMR855>3.0.CO;2-V

24. Bakuzis, P. and Bakuzis, M.L.F., Org. Chem., 1981, vol. 46, pp. 235-239. https://doi.org/10.1021/jo00315a002

25. Semakov, A.V. and Klochkov, S.G., Chem. Nat. Comp., 2020, vol. 56, pp. 254-256.

https://doi.org/10.1007/s10600-020-03000-7

26. Adekenova, A.S., Sakenova, P.Y., Ivasenko, S.A., Khabarov, I.A., Adekenov, S.M., and Berthod, A., Chromatografia, 2016, vol. 79, pp. 37-43. https://doi.org/10.1007/s10337-015-3000-1

27. Hussain, S. and Sharma, M., J. Phys. Sci., 2010, vol. 21, pp. 99-107.

28. Acton, N. and Klayman, D.L., Planta Med., 1985, vol. 51 , pp. $441-442$.

https://doi.org/10.1055/s-2007-969543

29. Li, A., Sun, A., and Liu, R., J. Chromatogr. A, 2005, vol. 1076, pp. 193-197.

https://doi.org/10.1016/j.chroma.2005.04.042

30. Coronado-Acevesa, E.W., Velazqueza, C., RoblesZepeda, R.E., Jimenez-Estrada, M., Hernandez-Martinez, J., Galvez-Ruiz, J.C., and Garibay-Escobar, A., Pharm. Biol., 2016, vol. 54, pp. 2623-2628. https://doi.org/10.3109/13880209.2016.1173067

31. El-Feraly, F.S. and Chan, Y.-M., J. Pharm. Sci., 1978, vol. 67 , pp. $347-350$. https://doi.org/10.1002/jps.2600670319

32. Macias, F.A., Galindo, J.C.G., and Massanet, G.M., Phytochemistry, 1992, vol. 31, pp. 1969-1977. https://doi.org/10.1016/0031-9422(92)80343-D

33. Kalsi, P.S., Kaur, B., and Talwar, K.K., Indian J. Chem., 1985, vol. 24B, pp. 835-839.

Translated by S. Sidorova 